посібник з інвестування в приватні компанії для отримання максимального прибутку/ Пер. 3 англ.. За наук. Ред.. Т.В. Герасимової. Дніпропетровськ: Баланс Букс, 2006. - 416 с.

8. Кинг А.М. Тотальное управление деньгами. - СПб.: Полигон, 1999. - 448 с.
9. Дамодаран А. Инвестиционная оценка: Инструменты и техника оценки любых активов/ А. Дамодаран; пер. с англ. Д. Липинского и др. М.: Альпина Бизнес Бук, 2004. - 342 с.

Эксперт редакционной коллегии к.э.н., доцент УкрГУЖТ Полякова Е.Н.

\author{
УДК: 656.2:[658.14+658.152]
}

\title{
ЩОДО ПИТАННЯ ОЦІНКИ ЕФЕКТИВНОСТІ ДІЯЛЬНОСТІ ЗАЛІЗНИЧНОГО ТРАНСПОРТУ
}

\author{
Задоя В.О., к.е.н., доцент (ДНУЗТ)
}

У статті наводиться аналіз розбіжностей при визначенні поняття ефективності залізничного транспорту. Такі обмеження як довжина вантажного потягу, впровадження новітніх технологій також є иентральним фактором ефективності залізничного транспорту, а сучасна інформачійна технологія дозволяє поліпшити і більш ефективно обслуговувати транспорту інфраструктуру, удосконалити процес комунікації з клієнтами та автоматизувати процес управління. Загалом, причини розбіжностей, стосовно визначення ефективності залізничного транспорту у різних країн, залежать від конкретних факторів даного регіону. Подальші важелі впливу на ефективність залізничних систем, які можуть бути реалізовані урядом і регулюючими органами, включають: відкриття ринку транспортних послуг для конкуренції; забезпечення сталого, надійного фінансування для поліпшення залізничної інфраструктури; заходи підвищення мобільності громадян і якість обслуговування населення; зменшення впливу на оточуюче середовище. Також важливо, щяоб уряд та керівні органи залізниці чітко визначили, як головну мету - підтримку суспільних пріоритетів (мобільність, екологічну та соиіальну значимість).

Ключові слова: залізничний транспорт, ефективність залізничних систем, державні субсидї, доходи, витрати.

\section{К ВОПРОСУ ОЦЕНКИ ЭФФЕКТИВНОСТИ ДЕЯТЕЛЬНОСТИ ЖЕЛЕЗНОДОРОЖНОГО ТРАНСПОРТА}

\author{
Задоя В.А., к.э.н., доцент (ДНУЖТ)
}

В статье приводится анализ разногласий при определении понятия эффективности железнодорожного транспорта. Такие ограничения как длина грузового поезда, внедрение новейших технологий также является иентральным фактором эффективности железнодорожного транспорта, а современная информачионная технология позволяет улучшить и более эффективно обслужсивать транспортную инфраструктуру, усовершенствовать процесс коммуникации с клиентами и автоматизировать процесс управления. В общем, причины разночтений, при определении эффективности железнодорожного транспорта в разных странах, зависят от конкретных факторов данного региона. Дальнейшие рычаги влияния на эффективность железнодорожных систем, которые могут быть реализованы правительством и регулирующими органами, включают: открытие рынка транспортных услуг для конкуренции; обеспечение устойчивого, надежного финансирования для улучшения железнодорожной инфраструктуры; меры повышения мобильности граждан и качество обслуживания населения; уменьшение влияния на окружающую среду. Также важно, чтобы правительство и органы управления железной дороги 
четко определили, как главную цель - поддержание общественных приоритетов (мобильность, экологическую и сочиальную значимость).

Ключевые слова: железнодорожный транспорт, эффективность жселезнодорожных систем, государственные субсидии, доходы, расходы.

\section{QUESTIONS FOR EVALUATION OF EFFICIENCY RAILWAY}

\section{Zadoia V.A., Candidate of Economic Sciences, associate professor (DNUZT)}

The article presents an analysis of the differences in the definition of the efficiency of rail transport. Such restrictions as the length of freight trains, the introduction of new technologies as a central factor in the efficiency of rail transport and modern information technology can improve and better serve transport infrastructure to improve the communication process with customers and automate the management process. In general, the reasons for differences in respect of determining the effectiveness of rail transport in different countries, depending on the specific factors of the region. Further leverage the efficiency of rail systems that can be implemented by the government and regulatory bodies include: the opening of the transport market to competition; sustainable, reliable funding to improve railway infrastructure; measures increasing mobility of citizens and the quality of services; reduce the impact on the environment. It is also important that the government and the governing bodies of the railway clearly identified as the main goal - to support social priorities (mobility, environmental and social value).

Keywords: rail, rail systems efficiency, state subsidies, revenue, expenses.

Постановка проблеми та ї̈ зв'язки з науковими чи практичними завданнями. Проблеми підвищення ефективності залізничного транспорту викликають інтерес у всьому світі. Ця тема цікавить як управлінців залізничної галузі та їхніх конкурентів в даному сегменті ринку, так і керівництво відповідних міністерств і відомств.

Кілька недавніх досліджень показують, що європейські залізниці відрізняються за своєю ефективністю. На основі порівняння європейських залізниць 3 деякими залізничними мережами країн, що не входять до складу $\mathrm{CC}$, отримуємо додаткові свідчення того, що існують значні прогалини у визначенні самого терміна «ефективність залізничного транспорту».

На сьогоднішній момент зрозуміло, що деяким європейським залізницям вдалося досягти високого рівня ефективності, а діяльність інших, з причин, що залежать від діяльності керівництва та / або уряду, може бути класифікована, як відносно неефективна.

Додаткові дослідження науковців щодо основних показників ефективності залізничного транспорту, підтверджують існування прогалин у визначенні ефективності залізничного сполучення між залізницями. Відмінності в ефективності використання активів, продуктивності праці, тарифних ставок i коефіцієнтів, доходів i витрат, $є$ ключовими показниками для даного дослідження.

\section{Постановка завдання. Сьогодні} зрозуміло, що 3 одного боку, залізниці знаходяться під пресингом, 3 метою зберегти витрати на низькому рівні, часто через тиск ринку або через відсутність державної підтримки внаслідок конкуруючих національних пріоритетів. 3 іншого боку, соціальна значимість залізничних пасажирських i вантажних перевезень після майже десятиліття стагнації ринку, вимагає додаткових інвестицій в залізничну інфраструктуру і рухомий склад.

Наукові дослідження залізничної галузі показують, що існує потенціал для підвищення ефективності ऑii діяльності. Бенчмаркінговий аналіз [1] висвітлює проблеми європейських залізниць, як систем 3 різними показниками ефективності діяльності.

Аналіз останніх досліджень $і$ публікацій. Питаннями підвищення ефективності та конкурентоспроможності залізничного транспорту в різний час займались такі вчені: Аксьонов I.М. [2], Бараш Ю.С.[3], Гненний О.М. [4], Мукмінова Т.О.[5] та ін.

У працях закордонних авторів А.Бек, Х.Бенте та М.Шилінга [6] відзначається, що критерії оцінки ефективності транспортної системи залежать від множини факторів, як суб'єктивних так і об'єктивних і наведено систему їі оцінювання.

Виділення невирішених частин загальної проблеми. Актуальність обраної теми дослідження обумовлена необхідністю удосконалення діючої системи оцінки показників ефективності залізничного транспорту.

Метою cmammi $є$ вивчення досвіду оцінювання ефективності залізничного 
транспорту та розробка системи критеріїв на основі фінансових показників діяльності залізничного транспортного комплексу.

Виклад основного матеріалу. У розвитку залізничного транспорту зацікавлено і населення країни, i державні органи управління через позитивний вплив на тенденції мобільності населення, і реальний потенціал для поліпшення процесу землекористування у міських центрах. Відносно низький вплив на навколишнє середовище в порівнянні 3 іншими видами транспорту, також є позитивним чинником. Зрозуміло, що в результаті цих та інших переваг, уряд повинен бути зацікавлений у розвитку інвестиційного процесу для підвищення потенціалу залізничної мережі і державні органи влади будуть зацікавлені у тому, щоб інвестиції в залізничну галузь отримали найкращу віддачу на вкладений капітал.

В цілому, результати та суспільні вигоди мають велике значення, але мінімізація витрат i державна фінансова підтримка вирішує все.

У цьому контексті, під ефективною діяльністю залізниць розуміють отримання прибутку, враховуючи інвестиції, вкладені в експлуатацію, технічне обслуговування та оновлення рухомого складу. Це може бути оцінено за допомогою порівняно ефективного використання інвестицій в матеріальні активи, відносно високою продуктивністю основних фондів (одиниця вимірювання - поїздо-км загального пробігу), зниженням витрат або відносно високим рівнем продуктивності праці.

Тим не менш, ефективність є широким терміном 3 багатьма потенційними визначеннями. Щоб визначити рівень ефективності діяльності транспортної системи можливо застосувати показники іiі енергоефективності, продуктивності, надійності або якості. Але, на мій погляд, раціонально розглядати поняття «ефективність залізничного транспорту» 3 фінансової точки зору.

Кожна національна залізниця має унікальні характеристики, які, безсумнівно, впливають на іiі працездатність. Це може виражатися формою організаційної структури залізниці, пропускною спроможністю або ж щільністю мережі. Субсидії в залізничний транспорт або річний дефіцит платіжного балансу може бути прийнятним в одних країнах, а в інших - ні. Топографія є ще одним фактором. Наприклад Швейцарія і Японія - обидві держави
3 високою концентрацією гірської місцевості, що здорожує будівництво та обслуговування залізничної інфраструктури [7]. Розгалуженість транспортної мережі і щільність населення також впливають на ефективність використання рухомого складу та інших активів (Франція, Швеція та Канада - країни, що мають низьку щільність населення, у порівнянні 3 Бельгією, Німеччиною або Швейцарією) [7].

В цих країнах доступні інвестиційні фонди державної підтримки розвитку транспортної залізничної системи. Але, останнім часом, досить часто виникає ситуація дефіциту коштів для підтримки транспортних операцій в перспективі. Наприклад, у Сполучених Штатах, кілька губернаторів заблокували виділення коштів у програму федерального розвитку високошвидкісного залізничного руху тому, що не хочуть нести відповідальність за інвестування державних коштів без чіткої програми зменшення майбутніх експлуатаційних витрат [8].

У Європі та в інших країнах світу, багато операторів залізничних перевезень і компанійвласників інфраструктури отримали суттєву державну підтримку у наслідок розуміння того факту, що добре функціонуюча транспортна залізнична система важлива для досягнення основних суспільних цілей i потреб екологічних, соціальних, економічних й ін.

Дуже важливо сприймати ці фактори до уваги для розуміння відмінностей в ефективності діяльності залізничного транспорту різних країн.

Розглядаючи поняття ефективності залізничного транспорту доцільно звернути увагу на два фактори (функціiі): інфраструктурну складову (як правило, пов'язана з матеріальними активами та транспортною мережею) i операційну діяльність (пов'язана 3 рухом потягів). Для кожної 3 цих функцій, витрати (інвестиційні або експлуатаційні) і доходи (або від діяльності, або субсидії/субвенції) можуть бути розділені. Потрібно відмітити, що 3 точки зору суспільних інтересів, обсяг субсидій залежить від показників доходу на ринку перевезень та рівня загальних витрат залізниці.

Наприклад, у своїх дослідженнях А.Бек [9] пропонує застосовувати вимірники ефективності залізничного транспорту, групуючи їх в залежності від інфраструктурної та експлуатаційної складової транспортного процесу (Рис. 1). 


\begin{tabular}{|c|c|c|}
\hline & Експлуатація & Інфраструктура \\
\hline Витрати & $\begin{array}{l}\text { - інвестиції в рухомих склад } \\
\text { - трудові ресурси }\end{array}$ & $\begin{array}{l}\text { - інвестиційний капітал } \\
\text { • технічне обслуговування та } \\
\text { ремонт }\end{array}$ \\
\hline Доходи & $\begin{array}{l}\text { - тарифні доходи } \\
\text { • державне фінансування } \\
\text { (субсидії, субвенції й ін.) }\end{array}$ & $\begin{array}{l}\text { - плата за доступ до мережі } \\
\text { • державне фінансування (субсидії, } \\
\text { субвенції й ін.) }\end{array}$ \\
\hline
\end{tabular}

Рис.1. Розподіл витрат та доходів від перевезень на експлуатаиійну діяльність та інфраструктурну складову

На європейських залізницях система критеріїв ефективності транспортних мереж включає рад показників (табл.1) [10]:

Таблиия 1

Показники ефективності транспортних систем європейських залізнииь

\begin{tabular}{|l|l|}
\hline \multicolumn{1}{|c|}{ Індикатор ефективності } & \multicolumn{1}{|c|}{ Зміст } \\
\hline $\begin{array}{l}\text { Покриття витрат (операційна } \\
\text { діяльність): виручка пасажирських } \\
\text { перевезень (вкл. державне } \\
\text { фінансування і фінансові доходи) }\end{array}$ & $\begin{array}{l}\text { Показує долю покриття загальних операційних витрат } \\
\text { залізниці за рахунок тарифних доходів, а також за рахунок } \\
\text { державного фінансування }\end{array}$ \\
\hline $\begin{array}{l}\text { Покриття витрат (інфраструктура): } \\
\text { виручка від використання } \\
\text { інфраструктури (оборот коштів і } \\
\text { фінансові доходи), тариф }\end{array}$ & $\begin{array}{l}\text { Показує, долю покриття загальних витрат на утримання } \\
\text { інфраструктури } \\
\text { за рахунок тарифних доходів, а також за рахунок } \\
\text { державного фінансування }\end{array}$ \\
\hline $\begin{array}{l}\text { Використання залізничної } \\
\text { інфраструктури }\end{array}$ & $\begin{array}{l}\text { Показує метод порівняння країн, при використанні їх } \\
\text { залізничної інфраструктури. }\end{array}$ \\
\hline $\begin{array}{l}\text { Використання операторів } \\
\text { вантажних / пасажирських } \\
\text { перевезень }\end{array}$ & $\begin{array}{l}\text { Показує, як порівнювати країни відносно числа } \\
\text { перевезених пасажирів і тонн вантажу в поіздо-км } \\
\text { загального пробігу }\end{array}$ \\
\hline $\begin{array}{l}\text { Пасажирський операційні витрати } \\
\text { на поїздо-км }\end{array}$ & Показує покриття витрат на пробіг поїздів \\
\hline Пасажирські доходи на поїзд-км & $\begin{array}{l}\text { Показує кількість тарифних доходів з розрахунку на один } \\
\text { пасажирський поїзд }\end{array}$ \\
\hline Тарифні доходи на пас-км & $\begin{array}{l}\text { Показує, скільки тарифних доходів в перерахунку на один } \\
\text { пасажиро-км }\end{array}$ \\
\hline Тарифні доходи на поїздо-км & $\begin{array}{l}\text { Показує, скільки тарифних доходів в розрахунку на пробіг } \\
\text { поїду }\end{array}$ \\
\hline Вантажні доходи на т-км & $\begin{array}{l}\text { Показує дохід вантажних операцій у розрахунку на тонно- } \\
\text { км }\end{array}$ \\
\hline $\begin{array}{l}\text { Витрати на інфраструктуру на } \\
\text { поїздо-км }\end{array}$ & $\begin{array}{l}\text { ооказує витрати на інфраструктуру при обслуговуванні / } \\
\text { ремонту на поїзд-км }\end{array}$ \\
\hline Витрати на інфраструктуру на т-км & $\begin{array}{l}\text { Показує витрати на інфраструктуру при обслуговуванні / } \\
\text { ремонту на тонно-км }\end{array}$ \\
\hline $\begin{array}{l}\text { Порівняння ставок тарифу } \\
\text { по країнах }\end{array}$ & $\begin{array}{l}\text { Показує порівняняя того, що бізнес / ринок платить в } \\
\text { кожній відповідній країні для переміщення товарів по } \\
\text { потенціал для конкурентної переваги }\end{array}$ \\
\hline
\end{tabular}

Визначальними факторами ефективності залізничного транспорту $\epsilon$ інфраструктурні обмеження, довжина потягів, структура вантажів, та новітні технології. Сучасні технологічні рішення дозволяють більш ефективно використати інвестиції, у тому числі, за рахунок кращої комунікації з клієнтами та автоматизації процесів.

Менеджмент залізничного транспорту безпосередньо впливає на ефективність діяльності залізниці. Розвиток політики інвестування капіталу в технології, які дозволяють знизити витрати на технічне 
обслуговування i підвищення купівельного попиту на залізниці є досяжною метою. Також доцільно розглянути питання додаткового розвитку інформаційних технологій (від більш зручних сайтів для клієнтів до автоматизованих систем обслуговування руху поїздів та технічного обслуговування).

На європейських залізницях досить популярний метод бенчмаркінг-аналізу з метою виявлення бар'єрів i важелів розвитку ефективності залізничного транспорту, та кращого розуміння шляхів удосконалення транспортного бізнесу компаній-операторів [11].

Подальші додаткові дослідження, або операційної діяльності залізничного транспорту, або сфокусовані на бенчмаркінгу у якості окремої теми, дозволять отримати додаткову інформацію, що розширить можливості державних регуляторів i менеджменту залізничних компаній підвищити ефективність діяльності залізниці, у тому числі, за рахунок оптимізації інтересів вантажних та пасажирських перевезень.

Зрозуміло, що ефективність транспортних систем, державне фінансування та доходи залізниці пов'язані між собою. Для розробки стратегії та операційного планування діяльності залізниці має вирішальне значення послідовність та обсяги державної фінансової підтримки. Як приклад, залізниці країн $€ C$, які повинні працювати на конкурентних ринках з невеликим ступенем державного регулювання. Для них обсяг державного фінансування має вирішальне значення для підтримки капіталоємких проектів, направлених на розвиток залізничного транспорту. Основні відмінності між країнами СC - чи державне фінансування для залізниць використовується в рамках державно-приватного партнерства, або ж це правило.

Уряди багатьох країн світу зробили кроки у напрямі подальшої приватизації та введення конкуренції на ринку транспортних послуг. Тим не менш, попри того, що залізничний ринок стає більш конкурентоспроможним та ефективним, суспільні пріоритети (тобто більша площа покриття, низькі ціни на квитки, енергоефективні технологіі) потребують державного регулювання та фінансової підтримки. Також адекватне та адресне державне фінансування необхідне для реалізації в рамках залізничних систем соціальних та екологічних проектів.

Висновок. Ефективність діяльності залізничного транспорту може бути визначена шляхом визначення ключових фінансових показників, таких як витрати (за категоріями) та доходи (за категоріями), i шляхом аналізу співставлення компонентів цих значень. Проте залежність від державних субсидій також може вважатися плюсом, якщо розглянути ці показники у контексті собівартості поїздо-км.

Подібно показникам оцінки ефективності операційної роботи, критерії вимірювання ефективності системи управління залізничною інфраструктурою обертаються навколо вартості і доходів від перевезення.

Подальші дослідження процесу удосконалення системи оцінювання ефективності залізничного транспорту потребують глибокого аналізу структури витрат і доходів від перевізної діяльності, що допоможе зрозуміти фактори (чинники) впливу. Наприклад, збільшення складності транспортної мережі, в результаті високої частки станційної роботи або висока густина перевезень, призводить до збільшення витрат на перевезення.

Важливо також розуміти, що потенційні економічні переваги можуть призвести до ускладнення ефективної діяльності залізничного транспорту. Тобто, підвищена складність перевізного процесу призводить до збільшення густини перевезень i, як наслідок, до зменшення пропускної спроможності. Більш висока ступінь електрифікації залізниці призведе до додаткових витрат на технічне обслуговування мережі, але знизить витрати на паливо. Нарешті, важливо враховувати амортизацію, особливо колійної інфраструктури, через високу капіталомісткість процесу.

\section{СПИСОК ЛІТЕРАТУРИ}

1. McNulty R. Realising the Potential of GB Rail: Report of the Rail Value for Money Study, Crown Copyright, London. - 2011. -[Електронний pecypc]. - Режим доступу: https://www.gov.uk/government/uploads/system/upl oads/attachment_data/file/4203/realising-the-

potential-of-gb-rail-summary.pdf. - Загол. 3 екр.

2. Аксьонов I. М. Ефективність пасажирських залізничних перевезень : [монографія] / I. М. Аксьонов. - Київ : Транспорт України, 2004. - 284 с.

3. Бараш Ю. С. Управління залізничним транспортом країни: [монографія] / Ю. С. Бараш. - Дніпропетровськ : ДНУЗТ, 2006. - 252 с.

4. Гненний О. М. Оцінка ефективності інвестиційних проектів на залізничному транспорті в умовах невизначеності і ризиків: автореф. дис. ... канд. екон. наук : 08.07.04 / О. М. 
Гненний; Укр. держ. акад. залізн. трансп. - Харків, 2004. $-21 \mathrm{c}$.

5. Мукмінова Т. А. Структура природної монополії на залізничному транспорті України та деякі підходи стосовно іï реформування / Т. А. Мукмінова // Вісн. ХНУ ім. Каразіна : зб. наук. пр. - 2002. -Вип. 565. - С. $79-87$

6. Arne Beck Railway Efficiency / Arne Beck, Heiner Bente, Martin Schilling // International Transport Forum Discussion Papers. - 2013. -12.

7. Encyclopedia Britannica [Електронний pecypc]. - $\quad$ Режим доступу :http://www.britannica.com/eb/article-9111233/UnitedStates United States. - Загол. з екрану.

8. Інвестиції в компанію «ІнтерБерінг» [Електронний ресурс]. - Режим доступу: . - Загол. 3 екрану.
9. Beck A. Barriers to Entry in Rail Passenger Services: Empirical Evidence for Tendering Procedures in Germany / A. Beck // European Journal of Transport and Infrastructure Research. - 2011. - Iss. 1. - P. 2041.

10. Санчес П. Эффективность, технические изменения и производительность в европейском железнодорожном секторе: Стохастический подход / П. Санчес, Д. Вилланова // Международный журн. экономики транспорта. - 2000 - № 1. - С. 55-76.

11. Аренков И. А. Бенчмаркинг и маркетинговые решения / И. А. Аренков, Е. Г.Багиев. - Санкт Петербург : Изд-во СПбУЭФ, 2001. $-94 \mathrm{c}$.

Рецензент д.е.н., професор ДНУЗТ Міщуенко М.I. Експерт редакційної колегії к.е.н., дочент УкрДУЗТ Токмакова І.В.

УДК: 656.61(477)

\title{
ДЕРЖАВНА ПІДТРИМКА СУДНОБУДІВНОЇ ГАЛУЗІ ЯК НАПРЯМОК РОЗВИТКУ ЕКСПОРТНОГО ПОТЕНЦААЛУ КРАЇНИ
}

\author{
Котлубай В.О., к.е.н., доцент (НУ «ОЮА»)
}

У статті розглядаються питання, присвячені розвитку експортного потенціалу Украӥни. Ключовим аспектом онтогенезу експортного потенціалу країни є розвиток суднобудівної галузі, що $\epsilon$ актуальним та стратегічним напрямом для будь-якої морської держави.

Суднобудування є однією з ключових галузей, яка може використовувати наш вітчизняний метал. Для відновлення суднобудування важливим також є розвиток транзитних коридорів, які йдуть через Україну.

Ключові слова: суднобудування, експорт, експортний потенціал, світова глобалізація, державна підтримка.

\section{ГОСУДАРСТВЕННАЯ ПОДДЕРЖКА СУДОСТРОИТЕЛЬНОЙ ОТРАСЛИ КАК НАПРАВЛЕНИЕ РАЗВИТИЯ ЭКСПОРТНОГО ПОТЕНЦИАЛА СТРАНЫ}

\author{
Котлубай В.А., к.э.н., доцент (НУ «ОЮА»)
}

В статье рассматриваются вопросы, посвященные развитию экспортного потенциала Украины. Ключевым аспектом онтогенеза экспортного потенциала страны является развитие судостроительной отрасли, что является актуальным и стратегическим направлением для любого морского государства.

Судостроение является одной из ключевых отраслей, которая может использовать наш отечественный металл. Для восстановления судостроения важным также является развитие транзитных коридоров, которые идут через Украину.

Ключевье слова: судостроение, экспорт, экспортный потенциал, мировая глобализация, государственная поддержкк.

(C) Котлубай В.О. 